University of Nebraska - Lincoln

DigitalCommons@University of Nebraska - Lincoln

USDA National Wildlife Research Center - Staff Publications
U.S. Department of Agriculture: Animal and Plant Health Inspection Service

2012

\title{
Biology of Invasive Monk Parakeets in South Florida
}

\author{
Michael L. Avery \\ USDA/APHIS/WS National Wildlife Research Center, michael.I.avery@aphis.usda.gov
}

Eric A. Tillman

USDA/APHIS/WS National Wildlife Research Center, eric.a.tillmann@aphis.usda.gov

Kandy L. Keacher

United States Department of Agriculture, kandy.I.keacher@aphis.usda.gov

John E. Arnett

Luke Air Force Base

Kelli J. Lundy

U.S. Department of Agriculture, elli.j.lundy@aphis.usda.gov

Follow this and additional works at: https://digitalcommons.unl.edu/icwdm_usdanwrc

Avery, Michael L.; Tillman, Eric A.; Keacher, Kandy L.; Arnett, John E.; and Lundy, Kelli J., "Biology of Invasive Monk Parakeets in South Florida" (2012). USDA National Wildlife Research Center - Staff Publications. 1093.

https://digitalcommons.unl.edu/icwdm_usdanwrc/1093

This Article is brought to you for free and open access by the U.S. Department of Agriculture: Animal and Plant Health Inspection Service at DigitalCommons@University of Nebraska - Lincoln. It has been accepted for inclusion in USDA National Wildlife Research Center - Staff Publications by an authorized administrator of DigitalCommons@University of Nebraska - Lincoln. 


\title{
BIOLOGY OF INVASIVE MONK PARAKEETS IN SOUTH FLORIDA
}

\author{
MICHAEL L. AVERY,${ }^{1,4}$ ERIC A. TILLMAN,${ }^{1}$ KANDY L. KEACHER,${ }^{1}$ \\ JOHN E. ARNETT, ${ }^{2,3}$ AND KELLI J. LUNDY ${ }^{1}$
}

\begin{abstract}
Monk Parakeets (Myiopsitta monachus) have been in Florida for $>40$ yrs, having been imported by the thousands for the pet trade. This conspicuous, charismatic species is now widely established, but relatively little is known about its population biology outside South America. We examined 845 parakeets from 385 nests from nest removals and collections by utility company personnel in 2003/2004 and 2006/2007 to document body size and aspects of reproductive biology and primary molt. Body measurements confirm Monk Parakeets in south Florida belong to the monachus subspecies. Adult males averaged 1.5 to $3.5 \%$ larger than females, but the body mass of females exceeded that of males during March-May, the period of egg development. The breeding season in south Florida commences in late winter/early spring with fledglings first appearing in the second week of June. Nest contents (eggs plus nestlings) averaged 5.6 for multiple-entry nests compared to 4.9 for single-entry nests. Over $94 \%$ of the adults we examined were replacing primary feathers during June-August. The extent and timing of breeding and molt in south Florida are virtually identical to those in South America, although offset by $\sim 6$ months. Monk Parakeets in south Florida retain a fixed annual cycle characteristic of the ancestral population, but their flexible behavior enables them to adapt and thrive in new environments. Received 1 November 2011. Accepted 3 March 2012.
\end{abstract}

The Monk Parakeet (Myiopsitta monachus) is native to South America, occurring from central Bolivia and southern Brazil south to central Argentina (Forshaw 1989). The species has become established in the mainland United States, Puerto Rico, Bahamas, West Indies, England, Belgium, Italy, Spain, Israel, and elsewhere through accidental and purposeful introductions (Spreyer and Bucher 1998). The species first became established in the United States during the 1960s. The Monk Parakeet in Florida was first recorded breeding in Miami in 1969 and has been firmly established since the early 1970s (Owre 1973).

The U.S. Fish and Wildlife Service initiated a nationwide control and removal program in the early 1970s based on the species' reputation as an agricultural pest in South America. This program ended in 1975 and reduced the existing population by approximately one half (Neidermyer and Hickey 1977). The Monk Parakeet has thrived since 1975, however, in the USA and has become an urban/suburban species with no obvious factor limiting population growth. Monk Parakeets are unique among psittacines as they use sticks and twigs to construct bulky nests which house from

${ }^{1}$ U.S. Department of Agriculture, Wildlife Services, National Wildlife Research Center, Florida Field Station, 2820 East University Avenue, Gainesville, FL 32641, USA.

${ }^{2}$ Department of Wildlife Ecology and Conservation, University of Florida, Gainesville, FL 32611, USA.

${ }^{3}$ Current address: 56th Range Management Office, Luke Air Force Base, AZ 85309, USA.

${ }^{4}$ Corresponding author; e-mail: michael.1.avery@aphis.usda.gov one to many individual nesting chambers (Spreyer and Bucher 1998). Parakeets in south Florida build nests principally on man-made structures such as stadium light poles, cell towers, and electric utility facilities (Newman et al. 2008). They exploit backyard bird feeders and non-native ornamental plants for food. Adverse effects of predation, diseases, and parasites to Monk Parakeets have not been documented in the USA.

Aspects of Monk Parakeet natural history have been well-documented in its native range (e.g., Navarro and Bucher 1990, Navarro et al. 1992a, Martin and Bucher 1993, Eberhard 1998). Nestsite selection (Burger and Gochfeld 2000, Pranty 2009), food habits (Hyman and Pruett-Jones 1995, South and Pruett-Jones 2000), population growth (Van Bael and Pruett-Jones 1996), nestling growth and development (Caccamise 1980), and population genetics (Russello et al. 2008, Gonçalves da Silva et al. 2010) have been studied in the USA, but other basic life history characteristics have not been quantified. We examined Monk Parakeets from south Florida to document their size, reproductive biology, and primary molt. We assessed variation between males and females and among seasons in these characteristics; the first analysis of a Monk Parakeet population outside its native range.

\section{METHODS}

Sources of Birds.-We obtained birds at two different times. Personnel with Florida Power and Light Company removed 335 nests from distribution poles in Miami-Dade and Broward coun- 
ties during January-October in 2003 and 2004 to help prevent power outages (Tillman et al. 2004). Utility company personnel trapped parakeets during nest removals by adapting a method developed in Argentina (Martella et al. 1987). Utility crews approached parakeet nest structures after dark, covered one or two nest entrances using long-handled nets, and then captured birds as they flew from the nest (Avery et al. 2006). The netted birds were euthanized with carbon dioxide as were any nestlings remaining inside the nest. All birds from a given nest structure were bagged together with a record sheet detailing location and characteristics of the nest structure. The number of entrances was recorded when a nest structure was removed, but the number of nest chambers within the nest structure was not ascertained. Thus, we used the number of entrances as a minimum estimate of the number of nest chambers. All contents from a single nest structure were comingled during the removal process. Thus, we could not assign contents to individual nest chambers for multi-chamber structures. The carcasses were frozen and shipped overnight to the Florida Field Station of the USDA's National Wildlife Research Center, Gainesville, Florida for necropsy. We tagged each carcass with a unique number and stored the necropsied carcasses in freezers. Most of the carcasses were discarded in 2010 when they spoiled following failure of one of the freezers.

We conducted field evaluations of diazacon, a candidate contraceptive for Monk Parakeets in electric utility substations in 2006 and 2007 (Avery et al. 2008). Utility workers removed 50 nests during April and May as part of the diazacon study at four substations which served as untreated control study sites. There was no effort to trap adults, but we documented the contents of the 50 nests.

Body Measurements and Primary Molt.-We measured body mass of each bird on a digital scale. We measured wing chord, flattened wing, tail length, tarsus, and exposed culmen (from the anterior edge of the cere) for adults and fledglings (Baldwin et al. 1931). We examined the primary feathers of each wing and scored molt following Ginn and Melville (1983): 0 - old; 1 - missing or completely in pin; 2 - just emerging from sheath up to $1 / 3$ grown; 3 - new feather $1 / 3$ to $2 / 3$ grown; 4 - new feather $>2 / 3$ grown with waxy sheath remaining; 5 - fully grown new feather. The maximum score for each wing was 50 , signifying all fully grown, new feathers. We combined the molt scores for both wings (maximum score $=$ 100) and summarized the results by month of collection. We distinguished fledglings from older birds during June-September by the fresh, unworn condition of their recently molted plumage (Navarro et al. 1992b). We also noted that juveniles had more green on crown and facial feathers and less yellow on the breast and belly compared to adults at this time of year.

We dissected each adult and fledgling to identify males and females, and we measured the diameter of the largest ovum or follicle in adult females. We assumed the ova and follicles were spherical and converted the linear measurement to volume. We also noted the presence or absence of an incubation patch (Manuwal 1974). We measured the length and width of both testes of adult males. We calculated total testicular volume (Møller 1991), summarized the results by month, and evaluated population level changes throughout the year. Few adults were collected in September, and we combined that month with October in all analyses. We used one-way analyses of variance for statistical testing unless otherwise stated.

\section{RESULTS}

Nesting Biology.-Monk Parakeets in south Florida are seasonal breeders. Testes volume peaked in March-April and steadily decreased thereafter (Fig. 1A). Females had the same temporal pattern as mean size of the largest follicle or ovum increased almost a thousand-fold from February to March and rapidly diminished after May (Fig. 1B). Nests with eggs occurred from 22 March through the first week of July (Fig. 2). The nestling period extended from 21 April to 21 July, except for one nest with two nestlings removed in late August. Total contents (eggs plus nestlings) of nest structures ranged from one to 12. Average ( \pm SE) contents of multiple-entry nests on distribution poles $(5.6 \pm$ $0.5 ; n=36)$ exceeded $\left(F_{1,74}=5.57 ; P=0.021\right)$ those of single-entry structures $(4.4 \pm 0.2 ; n=$ 40; Table 1).

We recorded incubation patches for 52 of 66 (78\%) females during April-July. Eight of 104 (7.7\%) females examined in other months had incubation patches. Females having incubation patches $(n=52$, mean $\pm \mathrm{SE}=117.8 \pm 1.1 \mathrm{~g})$ during April-July were heavier $\left(P<0.001 ; F_{1,64}\right.$ $=17.47)$ than those without $(n=14$, mean \pm SE 

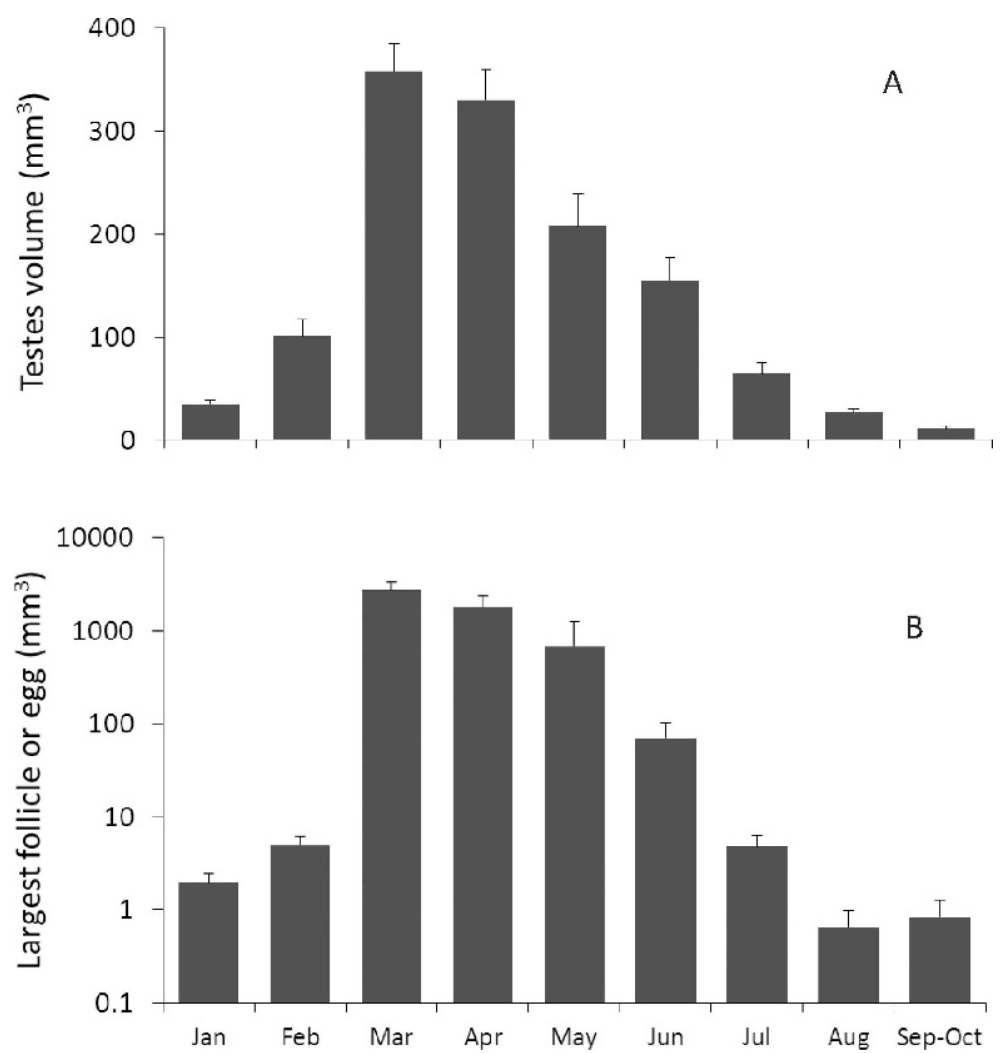

FIG. 1. Monthly mean testes volume of adult male (A) and mean size of the largest follicle or ovum of adult female (B) Monk Parakeets collected in south Florida, 2003-2004. Capped vertical bars denote 1 SE.

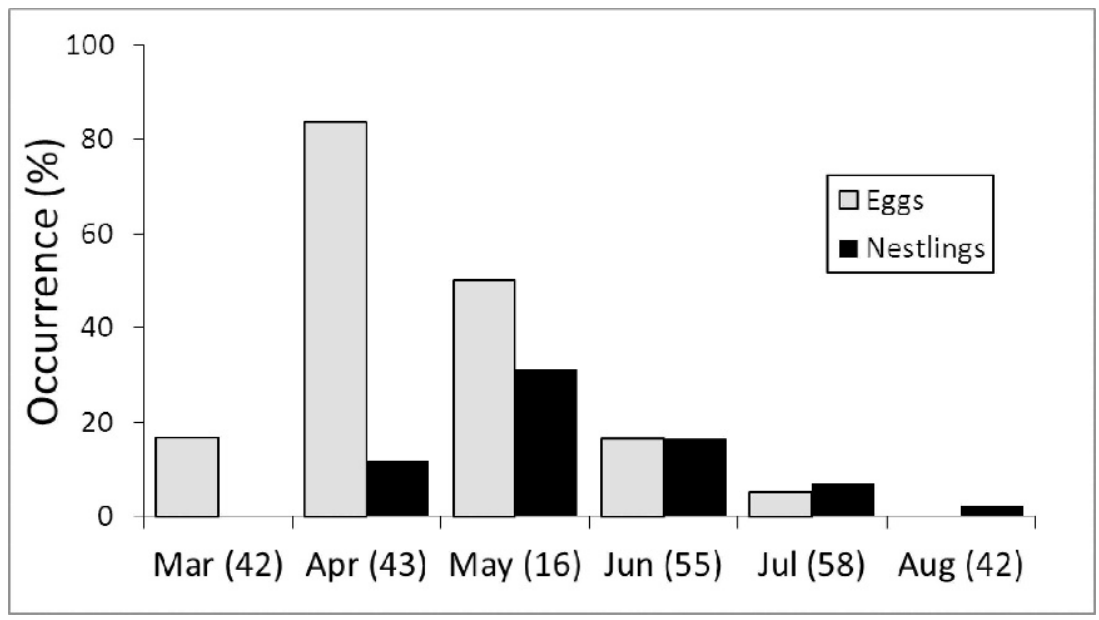

FIG. 2. Percent occurrence of eggs and nestlings in Monk Parakeet nest structures removed from electric utility distribution poles in south Florida, 2003-2004. Numbers of nest structures removed each month are in parentheses. Nests removed in January (19), February (44), September (5), and October (11) contained no eggs or nestlings. No removals occurred in November or December. 
TABLE 1. Productivity (eggs plus nestlings) of Monk Parakeet nests removed from electric utility facilities in south Florida. Nests were removed from street-side distribution poles in 2003/2004 (Mar-Jul), and those from 2006/2007 (AprMay) were removed from substations. Nests with zero contents are not included.

\begin{tabular}{|c|c|c|c|c|c|c|c|c|c|}
\hline \multirow[b]{2}{*}{ Nest openings } & \multicolumn{3}{|c|}{ Distribution poles (2003/2004) } & \multicolumn{3}{|c|}{ Substations (2006/2007) } & \multicolumn{3}{|c|}{ Totals } \\
\hline & $n$ & Mean & SE & $n$ & Mean & SE & $n$ & Mean & SE \\
\hline 1 & 40 & 4.4 & 0.2 & 45 & 5.3 & 0.2 & 85 & 4.9 & 0.2 \\
\hline 2 & 30 & 5.4 & 0.5 & 1 & 7.0 & N/A & 31 & 5.5 & 0.4 \\
\hline 3 & 6 & 6.8 & 1.6 & 1 & 6.0 & N/A & 7 & 6.3 & 1.4 \\
\hline
\end{tabular}

$=107.6 \pm 2.5 \mathrm{~g})$. No male parakeet had an incubation patch.

Fledglings first appeared during the second week of June. Birds frequently escaped during nest-removal operations, and there was no way to know whether the escapees were adults or fledglings. We narrowed the uncertainty regarding number of fledglings per nest by examining records $(n=14)$ where no escapes occurred and where the nest structure had just one opening. These data suggest three fledglings/pair was the norm (Fig. 3).

Three of 50 nests at substations had zero contents. Forty-five of the remaining 47 nests had a single entry hole (Table 1). The contents of the single-entry nest structures from substations exceeded $\left(P=0.007 ; F_{1,84}=7.67\right)$ those from distribution poles (Table 1). We collected 190 nestlings from 35 substation nests. The range in nestling body mass within broods was as much as $96 \mathrm{~g}$ and, across all broods, body mass of nestlings ranged from 3.7 to $143.4 \mathrm{~g}$ (Fig. 4). The mean body mass of nestlings exceeded that of adults in eight broods.

Body Size.-Adult male parakeets were slightly but consistently larger than adult females $(P<$
0.025) except for tail length $(P=0.996)$ across the study period (Table 2). Mean adult female body mass temporarily exceeded that of males during the period of egg development in MarchMay, but males were heavier overall $(P=0.008$; Fig. 5). Fledgling males were consistently larger than fledgling females $(P<0.025)$ in all characters except wing chord $(P=0.063)$ and tail length $(P=0.288$; Table 2$)$.

Replacement of Primaries.-We examined 55 birds in the initial stage of replacing primary feathers. Dates of initiation of molt (P6) extended from the first week of April to the second week of July with 28 (51\%) occurring in June. The basic sequence of primary feather replacement started with $\mathrm{P} 6$, proceeded to $\mathrm{P} 7$, and then continued P5P8-P4-P9-P3-P10-P2-P1. This was the prevalent pattern, but there were many exceptions to the basic sequence. For example, P8 preceded P5 in $9 \%$ of the birds, and $\mathrm{P} 3$ preceded $\mathrm{P} 918 \%$ of the time.

Females initiated molt sooner, and average molt scores of males lagged slightly behind those of females each month of the study (Fig. 6). Molt scores of females averaged greater than those of males (paired $t$-test; $P=0.0064$; df $=69$;

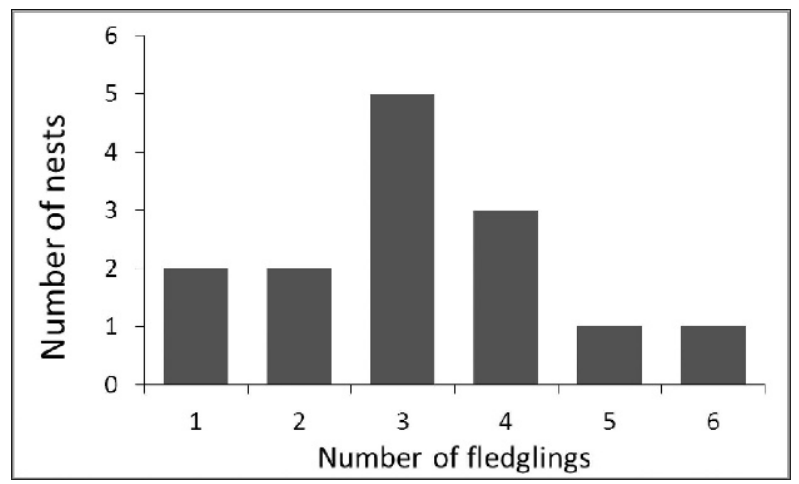

FIG. 3. Number of fledglings per nest structure with a single nest opening. Only nests where no escapees were recorded are included. 


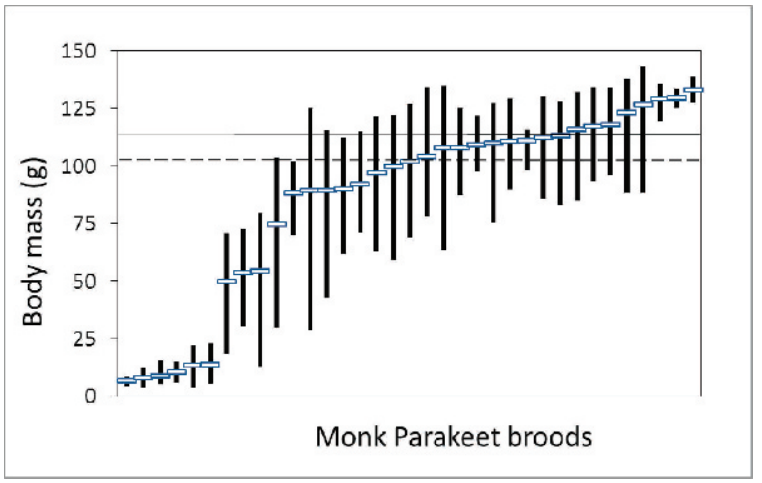

FIG. 4. Body mass of nestlings in 35 Monk Parakeet nests removed from electric utility substations in south Florida during April-May 2006 and 2007. Vertical bars denote maximum, minimum, and mean nestling body mass within each brood. The solid and dashed horizontal lines across the graph denote the mean body mass of adult (112.7 g) and fledgling (102.7 g) parakeets, respectively, collected in south Florida in 2003-2004.

$t$-statistic $=2.814)$ among 70 male-female pairs. The onset of primary molt in early to mid-April coincided with the first appearance of nestlings. Ninety-four percent (165 of 175) of adults examined during June-August were replacing primary feathers.

\section{DISCUSSION}

The invasive Monk Parakeet population in south Florida has retained basic biological characteristics of the native population in South America during $40+$ years. The timing has shifted $\sim 6$ months (Table 3), but Monk Parakeets in Florida exhibit a fixed annual cycle presumably governed by photoperiod (Spreyer and Bucher 1998).

We conclude the parakeets in our study belong to the monachus subspecies (Spreyer and Bucher 1998). Mean culmen and tarsus lengths for both male and female parakeets from south Florida exceed the upper end of the ranges given by Spreyer and Bucher (1998) for all subspecies except monachus. Measurements from south Florida parakeets overlap those given for monachus. The luchsi subspecies is closest in size to monachus, but luchsi occurs only in Bolivia and genetic evidence indicates south Florida Monk Parakeets originated from eastern Argentina and Uruguay (Russello et al. 2008).

The body measurements also demonstrate that, despite considerable overlap, male parakeets average 1.5 to $3.5 \%$ larger than females. Slight sexual dimorphism occurs in other monogamous psittacines, although detailed information is available for only a few species (Collar 1997, Masello and Quillfeldt 2003). Monk Parakeets are monogamous (Gonçalves da Silva et al. 2010), a condition often associated with reduced male-male

TABLE 2. Measurements of adult (Jan-Oct) and fledgling (Jun-Sep) Monk Parakeets from south Florida, 2003 and 2004. Tail length did not differ $(P>0.25)$ between males and females in each age class. Male measurements exceeded female measurements for all other characters $(P<0.025)$, except for fledgling wing chord $(P=0.063)$.

\begin{tabular}{|c|c|c|c|c|c|c|c|c|}
\hline \multirow[b]{3}{*}{ Character } & \multicolumn{4}{|c|}{ Adult } & \multicolumn{4}{|c|}{ Fledgling } \\
\hline & \multicolumn{2}{|c|}{ Male } & \multicolumn{2}{|c|}{ Female } & \multicolumn{2}{|c|}{ Male } & \multicolumn{2}{|c|}{ Female } \\
\hline & $n$ & Mean \pm SE & $n$ & Mean \pm SE & $n$ & Mean \pm SE & $n$ & Mean \pm SE \\
\hline Body mass (g) & 255 & $113.7 \pm 0.5$ & 280 & $111.6 \pm 0.6$ & 51 & $105.8 \pm 1.2$ & 69 & $100.5 \pm 1.1$ \\
\hline Wing chord $(\mathrm{mm})$ & 255 & $150.2 \pm 0.2$ & 280 & $147.9 \pm 0.2$ & 51 & $149.3 \pm 0.7$ & 69 & $147.5 \pm 0.7$ \\
\hline Wing flat (mm) & 255 & $155.3 \pm 0.2$ & 280 & $153.0 \pm 0.2$ & 51 & $152.6 \pm 0.7$ & 69 & $150.1 \pm 0.7$ \\
\hline Tail (mm) & 249 & $138.3 \pm 1.1$ & 273 & $138.3 \pm 0.8$ & 51 & $145.0 \pm 1.5$ & 69 & $142.3 \pm 1.9$ \\
\hline Tarsus (mm) & 64 & $18.2 \pm 0.1$ & 66 & $17.8 \pm 0.1$ & 39 & $18.2 \pm 0.1$ & 65 & $17.9 \pm 0.1$ \\
\hline Culmen (mm) & 253 & $20.4 \pm 0.1$ & 278 & $19.7 \pm 0.1$ & 51 & $19.6 \pm 0.1$ & 69 & $19.2 \pm 0.1$ \\
\hline
\end{tabular}




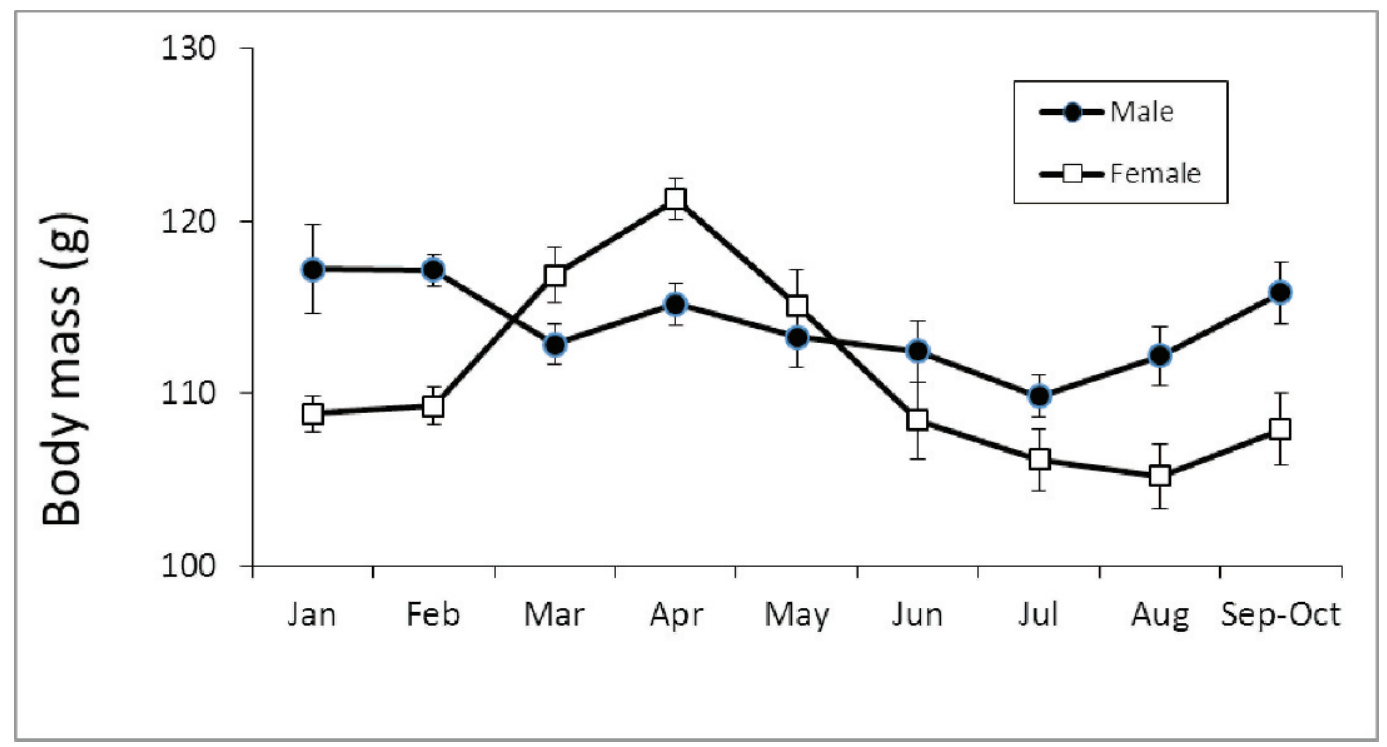

FIG. 5. Body mass of adult female Monk Parakeets exceeded that of males only during March-May, which corresponded to the period of egg-laying.

competition and lack of divergent size or secondary sexual characteristics (Collar 1997, Masello and Quillfeldt 2003).

We noted incubation patches only among females, consistent with field observations that female parakeets, not males, incubate (Eberhard 1998). Nestling Monk Parakeets in south Florida apparently undergo considerable recession of body mass prior to fledging (Fig. 4), consistent with findings from Argentina (Navarro and Bucher 1990). This phenomenon has been documented in other Psittaciformes (e.g., Burrowing Parrot [Cyanoliseus patagonus], Masello and Quillfeldt 2002) as well as in seabirds and swallows (Ricklefs 1968, Ydenberg et al. 1995), and is believed to result from interactions between parental provisioning and nestling departure decisions (Morbey et al. 1999).

Successful invasive species possess behavioral attributes that enable them to adapt and exploit key resources in the non-native range (Wright et al. 2010). Monk Parakeet populations in the

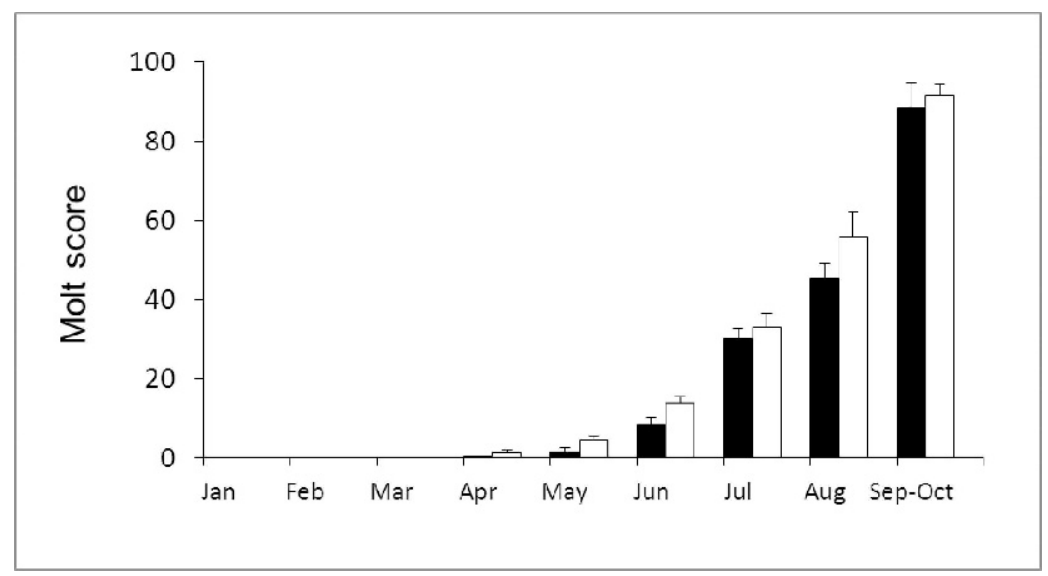

FIG. 6. Primary molt of adult male Monk Parakeets (dark bars) slightly lagged that of females (open bars). Maximum possible molt score is 100 indicating complete replacement of primaries on both wings. Capped vertical bars denote 1 SE. 
TABLE 3. Timing of biological attributes of Monk Parakeets in south Florida and Argentina.

\begin{tabular}{lll}
\hline \multicolumn{1}{c}{ Attribute } & \multicolumn{1}{c}{ Florida } & Argentina $^{\mathrm{a}}$ \\
\hline Testes enlargement begins & Feb & Aug \\
Female body mass $>$ male & Mar-May & Sep-Dec \\
Clutch initiation & mid-Mar & Oct \\
Peak period of remige molt & Jun-Aug & Feb-Mar \\
\hline
\end{tabular}

${ }^{\mathrm{a}}$ Spreyer and Bucher 1998.

USA are essentially urbanized (South and PruettJones 2000) in contrast to their native range where the species is mostly rural. The Monk Parakeet's ability to thrive in human-altered environments often creates conflicts and the need for aggressive management (Neidermyer and Hickey 1977, Avery et al. 2008). Flexible nest-building behavior, which contributes to the Monk Parakeet's success, is exactly what has created conflict. The species is a valued, charismatic component of local avifauna in many communities, but the propensity of these birds to select man-made structures as nesting substrates is increasingly at odds with safe, efficient operation of electric utility facilities (Newman et al. 2008). It would not be surprising if additional conflicts arise as Monk Parakeets colonize new environments (Sol et al. 1997), given their dietary flexibility (South and Pruett-Jones 2000) and dispersal ability (Gonçalves da Silva et al. 2010).

\section{ACKNOWLEDGMENTS}

Funding was provided by the National Wildlife Research Center and Florida Power and Light (FPL) Company through a cooperative research agreement with Pandion Systems Inc. (J. R. Newman, president). We appreciate the field assistance and support provided by J. R. Lindsay, Buddy Merchant, Donald Hoffmeier, and Joseph Wright of FPL during the project. J. R. Eberhard provided helpful comments on an earlier version of the manuscript.

\section{LITERATURE CITED}

Avery, M. L., C. A. Yoder, And E. A. Tillman. 2008. Diazacon inhibits reproduction in invasive Monk Parakeet populations. Journal of Wildlife Management 72:1449-1452.

Avery, M. L., J. R. Lindsay, J. R. Newman, S. PruettJones, and E. A. Tillman. 2006. Reducing Monk Parakeet impacts to electric utility facilities in south Florida. Pages 125-136 in Advances in vertebrate pest management (C. J. Feare and D. P. Cowan, Editors). Volume IV. Filander Verlag, Fürth, Federal Republic of Germany.

Baldwin, S. P., H. C. Oberholser, And L. G. Worley. 1931. Measurements of birds. Scientific Publications of the Cleveland Museum of Natural History. Volume 2. Cleveland, Ohio, USA.

Burger, J. AND M. GoCHFELD. 2000. Nest site selection in Monk Parakeets (Myiopsitta monachus) in Florida. Bird Behavior 13:99-105.

CACCAMISE, D. F. 1980. Growth and development of major body components in the Monk Parakeet. Wilson Bulletin 92:376-381.

Collar, N. J. 1997. Family Psittacidae (parrots). Pages 280-477 in Handbook of the birds of the world. Volume 4 (J. del Hoyo, A. Elliott, and J. Sargatal, Editors). Lynx Edicions, Barcelona, Spain.

Eberhard, J. R. 1998. Breeding biology of the Monk Parakeet. Wilson Bulletin 110:463-473.

Forshaw, J. M. 1989. Parrots of the world. Third Edition. Lansdowne Editions, Melbourne, Australia.

GinN, H. B. AND D. S. Melville. 1983. Moult in birds. British Trust for Ornithology Guide Number 19. British Trust for Ornithology, Tring, England.

Gonçalves da Silva, A., J. R. Eberhard, T. F. Wright, M. L. Avery, AND M. A. Russello. 2010. Genetic evidence for high propagule pressure and longdistance dispersal in Monk Parakeet (Myiopsitta monachus) invasive populations. Molecular Ecology 19:3336-3350.

Hyman, J. AND S. PRuetT-Jones. 1995. Natural history of the Monk Parakeet in Hyde Park, Chicago. Wilson Bulletin 107:510-517.

MANUwAL, D. A. 1974. The incubation patches of Cassin's Auklet. Condor 76:481-484.

Martella, M., J. Navarro, And E. Bucher. 1987. Método para la captura de cotorras (Myiopsitta monachus) en sus nidos. Vida Silvestre Neotropical 1:52-53.

Martin, L. F. AND E. H. Bucher. 1993. Natal dispersal and first breeding age in Monk Parakeets. Auk 110:930 933.

Masello, J. F. AND P. QuillfeldT. 2002. Chick growth and breeding success of the Burrowing Parrot. Condor 104:574-586.

Masello, J. F. AND P. Quillfeldt. 2003. Body size, body condition and ornamental feathers of Burrowing Parrots: variation between years and sexes, assortative mating and influences on breeding success. Emu 103:149-161.

MøLleR, A. P. 1991. Sperm competition, sperm depletion, paternal care, and relative testis size in birds. American Naturalist 137:882-906.

Morbey, Y. E., R. C. YdenberG, H. A. Knechtel, And A. HARFENIST. 1999. Parental provisioning, nestling departure decisions and prefledging mass recession in Cassin's Auklet. Animal Behaviour 57:873-881.

NAVARRO, J. L. AND E. H. Bucher. 1990. Growth of Monk Parakeets. Wilson Bulletin 102:520-525.

Navarro, J. L., M. B. Martella, And E. H. Bucher. 1992a. Breeding season and productivity of Monk Parakeets in Cordoba, Argentina. Wilson Bulletin 104:413-424.

NAvarro, J. L., L. F. Martin, AND E. H. Bucher. 1992b. Use of remige molt for age-class identification in 
Monk Parakeets (Myiopsitta monachus). Hornero 13:261-262.

Neidermyer, W. J. AND J. J. Hickey. 1977. The Monk Parakeet in the United States, 1970-1975. American Birds 31: 273-278.

Newman, J. R., C. M. Newman, J. R. Lindsay, B. Merchant, M. L. Avery, and S. Pruett-Jones. 2008. Monk Parakeets: an expanding problem on power lines and other electrical utility structures. Pages 355-363 in Environmental concerns in rightsof-way management, Eighth International Symposium (J. W. Goodrich-Mahoney, L. Abrahamson, J. Ballard, and S. Tikalsky, Editors). Electric Power Research Institute, Palo Alto, California, USA.

OWRE, O. T. 1973. A consideration of the exotic avifauna of southeastern Florida. Wilson Bulletin 85:491-500.

PranTy, B. 2009. Nesting substrates of Monk Parakeets (Myiopsitta monachus) in Florida. Florida FieldNaturalist 37:51-57.

RICKLEFS, R. E. 1968. Weight recession in nestling birds. Auk 85:30-35.

Russello, M. A., M. L. Avery, And T. F. Wright. 2008. Genetic evidence links invasive Monk Parakeet populations in the United States to the international pet trade. BMC Evolutionary Biology 8:217.
Sol, D., D. M. Santos, E. Feria, and J. Clavell. 1997. Habitat selection by the Monk Parakeet Myiopsitta monachus during the colonization of a new area. Condor 99:39-46.

South, J. M. AND S. PruetT-Jones. 2000. Patterns of flock size, diet, and vigilance of naturalized Monk Parakeets in Hyde Park, Chicago. Condor 102:848-854.

Spreyer, M. AND E. BuCher. 1998. Monk Parakeet (Myiopsitta monachus). The birds of North America. Number 322.

Tillman, E. A., A. C. Genchi, J. R. Lindsay, J. R. NeWman, AND M. L. Avery. 2004. Evaluation of trapping to reduce Monk Parakeet populations at electric utility facilities. Vertebrate Pest Conference 21:126-129.

van Bael, S. and S. Pruett-Jones. 1996. Exponential population growth of Monk Parakeet in the United States. Wilson Bulletin 108:584-588.

Wright, T. F., J. R. EBERHARd, E. A. HobSON, M. L. Avery, AND M. A. RusSELlo. 2010. Behavioral flexibility and species invasions: the adaptive flexibility hypothesis. Ethology, Ecology and Evolution 22:393-404.

Ydenberg, R. C., C. W. Clark, And A. Harfenist. 1995. Intraspecific fledging mass variation in the Alcidae, with special reference to the seasonal fledging mass decline. American Naturalist 145:413-433. 